\title{
Response of dry seed yield of Faba bean "Vicia Faba, L." to spraying with amino acids, organic acids, (NAA) growth regulator and micro nutrients
}

\author{
Ismail, A. Y. and A.A.M. Fayed \\ Vegetable Crops Seed Production and Technology Department, \\ Horticulture Research Institute, Agriculture Research Centre, Cairo, Egypt.
}

\begin{abstract}
Field experiment were carried out at Sakha Horticultural Research Station, Agricultural Research Center, Egypt, during two successive winter seasons of 2017/2018 and 2018/2019 to study the effect of foliar spraying with some stimulate substances i.e; Green Miracle (G.M) at the rate of 3cm / L, Mono Potassium Phosphate (MKP) at the rate of $6 \mathrm{gm} / \mathrm{L}$, Naphthalene Acetic Acid (NAA) at the rate of $0.6 \mathrm{gm} / \mathrm{L}$, potassium silicate at the rate of $3 \mathrm{~cm} / \mathrm{L}$, fulvic acid at the rate of $1 \mathrm{gm} / \mathrm{L}$, Boron (B) at the rate of $1.5 \mathrm{gm} / \mathrm{L}$, Zinc (Zn) at the rate of $1.5 \mathrm{gm} / \mathrm{L}$ and (Zinc+ Boron) at the rate of $(1.5+1.5) \mathrm{gm} / \mathrm{L}$., besides, control spraying with tap water) on growth characters, dry seed yield and its components and chemical analysis of dry seeds of broad bean (Vicia $F a b a \mathrm{~L}) \mathrm{cv}$. Weaam. The experiments were arranged in a randomized complete block design with three replications. Seeds were sown in the $1^{\text {st }}$ week of November during the two seasons. The results indicated that all foliar spraying treatments increased vegetative growth characteristics, dry seed yield and its components and chemical constituents in dry seeds compared to control. Where as, foliar spraying with the Green miracle at the rate of $\mathrm{cm} 3 / \mathrm{L}$ was among best stimulant substance, since, markedly improved most of the studied characters, i.e. vegetative growth characteristics, dry seed yield and its components and chemical constituents in dry seeds. Treatments led to highly significant increased of all studied parameters followed by foliar spraying with Naphthalene Acetic Acid (NAA) at the rate of $0.6 \mathrm{gm} / \mathrm{L}$ and potassium silicate at the rate of $3 \mathrm{~cm} / \mathrm{L}$. compared to the other treatments or the control.
\end{abstract}

Keywords: Broad bean, Green miracle(G.M), Mono Potassium Phosphate (MKP), Naphthalene Acetic Acid (NAA), potassium silicate, fulvic acid, Boron (B), Zinc (Zn).

\section{INTRODUCTION}

Broad bean (Vicia faba, L.) is one of the major field crops grown in Egypt. It is an important source of protein for human and animal consumption and it plays a role in the crop rotation. Legumes are considered the main sources of proteins for human, where animal protein is more expensive (Sepetoglu, 2002 and Hubbell and Gerald, 2003). Meanwhile, growing broad bean under saline conditions might adversely affect germination and growth (Abd ElSamad and Shadadd, 2013). These conditions could be more severe if the saline conditions are associated with the calcareous soil problems. It was concluded that the calcareous conditions components are the most important limiting factors against nutrients availability.

Geeth and Galal (2014) obtained variable response of pea cultivars to spraying with amino acids containing substrate.

Naphthalene Acetic Acid (NAA) as a hormone, plays an important role in physiological process that include synthesis of growth regulators. Spraying plants with NAA might improve growth, thereby increase seed yield (Cho and Prinyawiwathul, 2008). Foliar spraying of NAA is potentially an antifungal agen (Michiewiczand, 1988). Plant height, fruit set and seed yield were improved with NAA spraying (Lee, 1990). Also, NAA enhanced the mobilization of photo assimilates into filling seeds (Ibrahim et.al 2007).

As for Zinc, zinc is an essential micronutrient for plants (Gupta, 1989). Zn deficiency of human is the fifth major cause of diseases and deaths in the developing countries (WHO, 2002), yet, its deficiency is a wide spread problem (Trehan and Sekhon, 1977). The immobilization of $\mathrm{Zn}$ in soils rich in $\mathrm{Ca} 2+$ has an important practical impact in the Zn deficiency of plants (Pendias and Pendias, 2001) probably due to its adsorption on surfaces of clay and $\mathrm{CaCO} 3$ (Trehan and Sekhon,1977). Moreover, Mahady (1990) found that foliar application of $\mathrm{ZnSO} 4$ for broad bean plants increased the number of pods plant and seed yield. Also, Ali and Mowafy (2003) reported that application of foliar spray with $\mathrm{Zn}(2 \%)$ slightly improved groundnut yield and its attributes as well as quality. Thalooth et al., (2005) found that foliar application with $\mathrm{Zn}$ had a positive effect on yield attributes. Added to that, foliar $\mathrm{Zn}$ application either at flowering or seed filling stages significantly increased number of pods/ plant, weight of pods /plant, number of seeds/ plant, weight of seeds/ plant, 100-pod weight, 100-seed weight, pod, seed and straw yield /fad (El-Habbasha et al., 2013).

Boron (B) is an essential micronutrient and plays a major role for plant growth and development (Pilbeam 
and Kirkby, 1983; Marschner, 1995). Providing a sufficient B supply is particularly important for yield pollination (Khayyat et al., 2007; Wojcik et al., 1999) and fruit quality. Boron deficiency in crops is more widespread than the deficiency of any other micronutrients (Gupta, 1993). The foliar application with micro nutrients especially boron not only have major effects on flower formation, carbohydrate and protein metabolism, increase pollen germination, pollen tube growth, and yield (Gerendas and Sattelmatcher, 1990). Also is for chloroplast formation and sink limitations (Tersahima and Evans, 1988).

The beneficial effects of silicon $(\mathrm{Si})$ are mainly linked with high deposition in plant tissues, which enhance its strength and stiffness, this led to a mechanical strength that reduces pest attacks and increase the light receiving position increase photosynthesis and promote growth (Epstein, 1999). Also it is supposed to reduce transpiration from the cuticle thus increasing resistance to salinity (Matoh $e t$ al., 1986). Some studies suggested that Si also acting a vigorous role in the biochemical processes in plant and could play a responsibility in the intracellular production of organic compounds (Fawe, 1998). Many scientists illustrated the role of silicon in plant resistance to both biotic and abiotic stress including drought (Hanafy et al., 2008 and Crusciol et al., 2009). Furthermore, Rakha (2014) showed that foliar application of potassium silicate significantly increased most of yield parameters and enhanced fruit quality of eggplant compared to control. Hussein and Muhammed (2017) reached that spraying eggplant by potassium silicate $(1.5 \mathrm{~g} / \mathrm{L})$ gave the highest plant height, leaves number per plant, leaf area, chlorophyll content, and plant yield, fruits number per plant, $\mathrm{P}$ and $\mathrm{K}$ percentages in fruits.

Mono-potassium phosphate (MKP), it is an effective and readily available fertilizers used in soil applications; MKP is a formulation with the lowest salt index and thus it considered the choice of foliar fertilizer for many crops (Ankorion, 1998). $\mathrm{K}$ is a macro elements with a main physiological functions as enzymes activation, protein synthesis, carbohydrate metabolism, osmoregulation, stomata movement, energy transfer, phloem transport, cation-anion balance, stress resistance, improves efficiency of plant water and sugar use for maintenance and normal growth functions. Potassium with phosphorus stimulate and maintain rapid root growth of plants (Marschner, 2005; Wang et al., 2013 and Salami and Saadat 2013). Sugar beet foliar application with potassium increase the biosynthesis of photosynthates. El-gamal (2009) stated that foliar spraying with potassium (1000 ppm) increased chemical compounds of sugar beet i.e., T.S.S, purity, sucrose, NPK uptake and total sugar. Fageria $e t$ al. (2009) stated that, foliar application of potassium, increased phytohormones and amino acids content.

Fulvic acids (FAs) are humic acids with a higher oxygen content and lower molecular weight ranging to a few hundred Daltons and can pass through micropores of biological or artificial membrane systems, whereas humic acids cannot, of larger molecule weights ranging to a few thousand Daltons (Bulgari et al., 2015). Fulvic acids have greater total acidity, greater numbers of carboxyl groups, and higher adsorption and cation exchange capacities than humic acid and may play roles as natural chelators in the mobilization and transport of micronutrients (Bocanegra et al., 2006). Fulvic acids can remain in soil solution even at high salt concentrations and at a wide range of pH (Zimmerli et al., 2008) and have longlasting potential to interact with plant roots. Also, fulvic acid is considered a soil organic fraction that is soluble in both acid and alkali. Moreover, Fulvic acid promotes some physiological processes depending on plant species, developmental stage, and application conditions. soil applications of a "humic substance" that was shown with analysis as $90.7 \%$ fulvic acid, increased fruit weight, fruit equatorial diameter, juice $\mathrm{pH}$, and vitamin $\mathrm{C}$ content of lemon (Citrus limon) trees, while, foliar applications of FA increased yield of maize under drought conditions (Anjum et al.,2011). In common bean, FA enhanced the numbers of root initials on hypocotyl sections, increased number and length of lateral roots of both Arabidopsis and tomato (Dobbss et al., 2007).

Fulvic acids enhanced the uptake of phosphate in beech and $\mathrm{N}$ content in maize (Eyheraguibel et al., 2008), increased chlorophyll content in both soybean and ryegrass (Chen et al., 2004). Added to that, fulvic acid is expected to influence the growth and yield of faba bean cultivars.

The present investigation was carried out to study the impact of spraying different concentrations of (FA) Fulvic acid on four faba bean cultivars (Noubaria 2, Sakha 1, Sakha 3, and Sakha 4) on morphological characters, yield, and some metabolic constituents of seeds.

\section{MATERIALS AND METHODS}

The field experiments were conducted at Sakha Horticultural Research Station, Agricultural Research Center, Egypt, during the two successive winter seasons of 2017/2018 and 2018/2019. The aim of the study was to asses the level of reduction in adverse effect of soil salinity stress on growth, dry seed yield and chemical 
components of broad bean (Vicia Faba, L) cv. Weaam. Soil samples at $50 \mathrm{~cm}$ depth were taken to determine

physical and chemical properties (Black, 1965 and Page et al., 1982) (Table 1).

Table (1): Physical and chemical analysis properties of the experiment soil.

\begin{tabular}{|l|c|c|}
\hline \multicolumn{1}{|c|}{ Components } & $\mathbf{1}^{\text {st }}$ season & $\mathbf{2}^{\text {nd }}$ season \\
\hline Soil Type & Salty & Salty \\
\hline Organic Matter \% & 1.79 & 43.83 \\
\hline Clay \% & 44.59 & 25.08 \\
\hline Silt \% & 24.66 & 30.97 \\
\hline Fine Sand \% & 30.75 & 32.22 \\
\hline Coarse Sand \% & 28.51 & 7.82 \\
\hline pH & 7.72 & 3.79 \\
\hline E.C. $(\mathrm{mmhos} / \mathrm{cm})$ & 3.70 & 4.13 \\
\hline CaCO3 \% & 4.39 & 62.7 \\
\hline Total N (ppm) & 63.4 & 15.00 \\
\hline Available (ppm) & 14.79 & 70.9 \\
\hline Available K(ppm) & 69.6 & \\
\hline
\end{tabular}

Nine treatments were included:

$\mathbf{T}_{1}$ : control (spraying with tap water).

$\mathbf{T}_{2}$ : Foliar application of Green Miracle (G.M) $(3 \mathrm{~cm} / \mathrm{L})$.

$\mathbf{T}_{3}$ : Foliar application of Mono Potassium Phosphate (MKP) $(6 \mathrm{gm} / \mathrm{L})$.

$\mathbf{T}_{\mathbf{4}}$ : Foliar application of Naphthalene Acetic Acid (NAA) (0.6 gm / L).

$\mathbf{T}_{\mathbf{5}}$ : Foliar application of potassium silicate $(3 \mathrm{~cm} / \mathrm{L})$.

$\mathbf{T}_{6}$ : Foliar application of fulvic acid (1 g. / L).

$\mathbf{T}_{7}$ : Foliar application of Boron (B) (1.5 g. / L).

$\mathbf{T}_{\mathbf{8}}$ : Foliar application of Zinc (Zn) (1.5 g. / L).

$\mathbf{T}_{\mathbf{9}}$ : Foliar application of (Zinc+ Boron) $(1.5+1.5 \mathrm{~g}$. / L).

Treatments were arranged in a randomized complete block design with three replications. Plot area was $11.2 \mathrm{~m}^{2}$ four ridges of four meter length and 0.7 meter. Seeds of broad bean cv. Weaam were obtained from the Horticulture Research Institute, Agricultural Research Center, Egypt and sown on the $1^{\text {st }}$ week in November during the two winter successive seasons. In hills at one side of ridges (25 $\mathrm{cm}$ apart).Other managements practices were followed according to the recommendations of Egyptian Ministry of Agriculture

Plants were sprayed three times at 30, 45 and 60 days after sowing. Each experimental unit received 2 liter solutions of each application using spreading agent (Super film at $1 \mathrm{~cm} / \mathrm{L}$.) to improve adherence of the spray to the plant foliage for increasing absorption by the plants (Mortvedt et al., 1991). The untreated plants (check) were sprayed with tap water and spreading agent.

Green miracle(Trade mark) is an anti transpirant Total amino acids not less than $3 \%$, Fatty alcohol 80

$\%$, other neutral alcohol $10 \%$, emulsifier and stabilizers $7 \%$ (obtained from local market).Mono potassium phosphate (MKP), Naphthalene Acetic Acid (NAA), potassium silicate, Fulvic acid, boron and zinc as sulphate form were also obtained from local market.

\section{Data recorded:}

\section{Vegetative growth characteristics:}

At flowering (50 days from sowing), five plants were randomly taken from each plot to evaluate vegetative growth characteristics i.e; plant height $(\mathrm{cm})$, number of leaves/plant, number of branches/plant, stem diameter ( $\mathrm{mm}$ ) and total fresh as well as dry weight/plant $(\mathrm{g})$. Plant parts (leaves and branches) were dried at $70^{\circ} \mathrm{C}$ till constant weight to determine dry weight.

\section{Dry seed yield and its components:}

At full seed ripening stage (120 days from sowing), a random sample of 5 plants were taken from each plot to estimate dry seed yield components 
i.e.; number of seeds/pod, seed weight/pod (g), seed index (100 seeds weight $\mathrm{g}$ ), seed yield (g/plant), while, dry seed yield /faddan was calculated from dry seed yield per plot.

\section{Chemical composition of dry seeds:}

Total nitrogen (\%) was determined by using the modified "Micro-Kjeldahl" method apparatus of Parnas and Wagner as described by Pregl (1945). Protein $(\%)$ was calculated in seeds by multiplying nitrogen (\%) content by 6.25 . Phosphorus (\%) was estimated spectrophotometrically in dry seeds according to the method described by Murphy and Riley (1962) as modified by John (1970). Potassium was determined by flame-photometrically as described by Brown and Lilleland (1946). Zinc (Zn) and boron (B) were extracted using DTPA, (Lindsay and Norvell, 1978).

\section{Statistical analysis:}

The obtained data were subjected to the statistical analysis of variance and treatment means were compared according to the least Significant
Differences (L. S. D.) test at 0.05 level) as described by Snedecor and Cochran (1980).

\section{RESULTS AND DISCUSSIONS}

\section{1-Vegetative growth characteristics:}

Data in Table (2) illustrated that all vegetative growth parameters of broad bean were significantly affected by the studied treatments. It can said that all treatments significantly enhanced all growth parameters expressed as plant height, number of leaves/plant, number of branches/plant and stem diameter as well as fresh and dry weight/plant compared to the control(tap water). Meanwhile, foliar spraying with the Green miracle (T2) at the rate of $3 \mathrm{~cm} / \mathrm{L}$ was among the best stimulant substances, since, it gave the high vegetative growth characteristics. That was not different from obtained foliar spraying with Naphthalene Acetic Acid (NAA) (T3) at the rate of $0.6 \mathrm{gm} / \mathrm{L}$ or potassium silicate (T5) at the rate of $3 \mathrm{~cm} / \mathrm{L}$. or spraying with fulvic acid(1 $\mathrm{g} / \mathrm{L})$. These results might be due to the beneficial effects of total amino acids in Green miracle.

Table (2): Vegetative growth characteristics of broad bean as affected by foliarspraying with growth improvers during the two winter seasons of 2017/2018 8and 2018/2019.

\begin{tabular}{|c|c|c|c|c|c|c|c|c|c|c|c|c|}
\hline \multirow[b]{2}{*}{ Treatments } & \multicolumn{6}{|c|}{$1^{\text {st }}$ season } & \multicolumn{6}{|c|}{$2^{\text {nd }}$ season } \\
\hline & $\begin{array}{c}\text { Plant } \\
\text { height } \\
(\mathbf{c m})\end{array}$ & $\begin{array}{c}\text { No. of } \\
\text { leaves/ } \\
\text { plant }\end{array}$ & $\begin{array}{c}\text { No. of } \\
\text { branches/ } \\
\text { plant }\end{array}$ & $\begin{array}{c}\text { Stem } \\
\text { diameter } \\
(\mathbf{m m})\end{array}$ & $\begin{array}{c}\text { Plant } \\
\text { fresh wt. } \\
\text { (g) }\end{array}$ & $\begin{array}{c}\text { Plant } \\
\text { dry wt. } \\
\text { (g) }\end{array}$ & $\begin{array}{c}\text { Plant } \\
\text { height } \\
(\mathrm{cm})\end{array}$ & $\begin{array}{l}\text { No. of } \\
\text { leaves/ } \\
\text { plant) }\end{array}$ & $\begin{array}{c}\text { No. of } \\
\text { branches/ } \\
\text { plant }\end{array}$ & $\begin{array}{c}\text { Stem } \\
\text { diameter } \\
(\mathrm{mm})\end{array}$ & $\begin{array}{c}\text { Plant } \\
\text { fresh wt. } \\
\text { (g) }\end{array}$ & $\begin{array}{c}\text { Plant } \\
\text { dry wt. } \\
\text { (g) }\end{array}$ \\
\hline $\mathrm{T} 1$ & 61.5 & 48.5 & 4.3 & 5.3 & 77.4 & 30.2 & 58.6 & 51.8 & 4.4 & 5.1 & 90.4 & 32.9 \\
\hline $\mathrm{T} 2$ & 91.7 & 71.3 & 6.6 & 7.6 & 140.1 & 44.6 & 93.5 & 79.5 & 7.1 & 8.5 & 147.5 & 51 \\
\hline $\mathrm{T} 3$ & 85.1 & 65.1 & 6.1 & 7.3 & 116.3 & 38.3 & 81.5 & 69.3 & 6.7 & 7.9 & 126.6 & 40.4 \\
\hline $\mathrm{T} 4$ & 90.1 & 65.4 & 6.5 & 7.9 & 129.2 & 40.9 & 87.5 & 75.2 & 6.5 & 8.1 & 142.3 & 44.9 \\
\hline $\mathrm{T} 5$ & 87.6 & 62.7 & 5.8 & 7.4 & 126.7 & 37.6 & 83.3 & 70.8 & 6.8 & 7.8 & 128.3 & 39 \\
\hline T6 & 87.6 & 62 & 6.1 & 7.5 & 124.7 & 35.7 & 81.4 & 72.8 & 6.3 & 7.9 & 118.8 & 36.2 \\
\hline $\mathrm{T} 7$ & 83.7 & 63.8 & 6 & 7.6 & 120 & 38.4 & 80.5 & 68.5 & 6.2 & 8.3 & 124 & 38.2 \\
\hline $\mathrm{T} 8$ & 83.1 & 61.8 & 5.6 & 7.3 & 107.3 & 39.4 & 83.6 & 66.5 & 6.6 & 7.8 & 126.3 & 39.5 \\
\hline T9 & 86.2 & 66.6 & 6.1 & 7.6 & 118 & 38 & 83.8 & 69.9 & 6.5 & 7.7 & 132.2 & 42.7 \\
\hline L.S. $D_{0.05}$ & 7.2 & 9.6 & 1.3 & 0.8 & 21.8 & 10.04 & 11 & 8.2 & 0.86 & 0.77 & 16.2 & 6.31 \\
\hline
\end{tabular}

$\mathbf{T}_{1}$ : control (spraying with tap water).

$\mathbf{T}_{2}$ : Foliar application of Green Miracle (G.M) $(3 \mathrm{~cm} / \mathrm{L})$.

$\mathbf{T}_{3}$ : Foliar application of Mono Potassium Phosphate (MKP) (6 gm / L).

$\mathbf{T}_{4}$ : Foliar application of Naphthalene Acetic Acid (NAA) $(0.6 \mathrm{gm} / \mathrm{L})$.

$\mathbf{T}_{\mathbf{5}}$ : Foliar application of potassium silicate $(3 \mathrm{~cm} / \mathrm{L})$.

$\mathbf{T}_{6}$ : Foliar application of fulvic acid (1 g. / L).

$\mathbf{T}_{7}$ : Foliar application of Boron (B) (1.5 g. / L).

$\mathbf{T}_{\mathbf{8}}$ : Foliar application of Zinc (Zn) (1.5 g. / L).

T9: Foliar application of (Zinc+ Boron) $(1.5+1.5$ g. / L). 
Geeth and Galal (2014) obtained similar results with pea. Abdel-Aziz and Geeth (2017) working on pea pointed out that foliar spraying with the Green miracle at a concentration of $3 \mathrm{~cm} / \mathrm{L}$ markedly improved most of the growth characters. Sharief and El-hamady (2017) on broad bean found that, foliar spraying of Naphthalene Acetic Acid (NAA) significantly affected, plant height and number of branches/plant. Abdel-Baky et al., (2019) on faba bean mentioned that applications of fulvic acid (FA) increased all vegetative characters (i.e., plant height, number of branches and leaves, and total dry weight/plant (Nesreen et al., 2012) showed that potassium silicate rates led to significantly increased plant height, number of leaves and branches/plant and dry weight of bean. The superiority of potassium silicate might be due to the role of $\mathrm{K}$ in mitigating the toxic effect of $\mathrm{Na}$ under salt stress (Tahir et al., 2006). Hashemi et al., (2010) reported that salinity decreased plant growth parameters (tissue fresh and dry weights). Application of potassium silicate to wheat improved plant height to 44 and $50 \mathrm{~cm}$ and increased shoot dry weight to 20.27 and $24.39 \mathrm{~g} /$ plant.

\section{2-Dry seed yield and its components:}

Concerning to the effect of some foliar application substances on broad bean dry seed yield, data in Tables (3) showed that these treatments led to a significant increase in dry seed yield .i.e.; number of seeds/pod, seed weight/pod $(\mathrm{g})$, seed index 100 seeds weight $(\mathrm{g})$, seed yield (g/plant), as well as, seed yield /fad compared to the control. Data also cleared that, spraying with the Green miracle (T2) at the rate of 3 $\mathrm{cm} / \mathrm{L}$ or by foliar spraying with Naphthalene Acetic
Acid (T3) (NAA) at the rate of $0.6 \mathrm{~g}$. / L or potassium silicate (T5) at the rate of $3 \mathrm{~cm} / \mathrm{L}$. gave high dry seed yield and its components compared with the other treatments or the control. The obtained resulted might be attributed to that the important effects of green miracle substance which contains total amino acids and the favorable effects of amino acids which plays an important role in plant resistance to biotic and abiotic stresses. Also, amino acid increase the content and activity of endogenous plant growth regulators, which promote growth of plant organs due to conversion into Indol Acetic Acid (IAA). Auxins promote growth, increase building metabolites, retard senescence, enhance cell division, chlorophyll accumulation and stimulate dry matter production as a result of higher photosynthetic activity, consequently increase translocation and accumulation of micro elements in plant organs as well as building blocks of proteins. These results are in agreement with those reported by Sharief and El-hamady(2017) working on broad bean. They mentioned that, adding NAA levels up to $60 \mathrm{ppm}$ significantly increased pods number, seeds /pod, 100seed weight (g), seed yield/plant and seed yield (ton/ha). Abdel-Baky et al., (2019) reported that foliar application with FA, significantly improved yield and its components (i.e.; number of pods/plant, weight of pods/plant, seed index, seed yield/plant and seed yield/faddan) of all studied faba bean cultivars. Nesreen et al., (2012) illustrated that, foliar spraying with potassium silicate gave the highest pods number and seed yield of bean. Moreover, Ismail and Shatta(2017) studied the effect of spraying potassium silicate on

Table (3): Dry seed yield and its components of broad bean as affected by foliarspraying with different substances during the two winter seasons of 2017/2018 8and 2018/2019.

\begin{tabular}{|c|c|c|c|c|c|c|c|c|c|c|c|c|}
\hline \multirow[b]{2}{*}{ Treatments } & \multicolumn{6}{|c|}{ 1st season } & \multicolumn{6}{|c|}{ 2nd season } \\
\hline & $\begin{array}{c}\text { No. of } \\
\text { seeds/po } \\
\text { d }\end{array}$ & $\begin{array}{c}\text { Dry seed } \\
\text { weight } \\
\text { (g/pod) }\end{array}$ & $\begin{array}{c}\text { Seed } \\
\text { index } \\
100 \text { seeds } \\
\text { wt. }(\mathrm{g})\end{array}$ & $\begin{array}{c}\text { Shell out } \\
\%\end{array}$ & $\begin{array}{c}\text { Dry seed } \\
\text { yield } \\
\text { (g/plant }\end{array}$ & $\begin{array}{c}\text { Dry seed } \\
\text { yield } \\
\text { (kg/fed) }\end{array}$ & $\begin{array}{c}\text { No. of } \\
\text { seeds/po } \\
\text { d }\end{array}$ & $\begin{array}{c}\text { Dry seed } \\
\text { weight } \\
\text { (g/pod) }\end{array}$ & $\begin{array}{c}\text { Seed } \\
\text { index } \\
100 \text { seeds } \\
\text { wt. }(\mathrm{g})\end{array}$ & $\begin{array}{c}\text { Shell out } \\
\%\end{array}$ & $\begin{array}{c}\text { Dry seed } \\
\text { yield } \\
\text { (g/plant }\end{array}$ & $\begin{array}{c}\text { Dry seed } \\
\text { yield } \\
\text { (kg/fed) }\end{array}$ \\
\hline $\mathrm{T} 1$ & 3.8 & 3.9 & 90.9 & 71 & 28.6 & 654.5 & 3.7 & 3.8 & 94.6 & 71 & 29 & 662.1 \\
\hline $\mathrm{T} 2$ & 5.8 & 6.5 & 138.5 & 81.7 & 41.2 & 927.8 & 5.9 & 6.5 & 132.6 & 83.9 & 41.6 & 951.6 \\
\hline T3 & 5.2 & 5.3 & 132 & 81 & 39.8 & 885.3 & 5.2 & 5.3 & 120.9 & 81.8 & 38.8 & 887.6 \\
\hline $\mathrm{T} 4$ & 5.5 & 5.7 & 128.5 & 77.2 & 35 & 800.8 & 5.3 & 5.8 & 121.1 & 77.8 & 41.4 & 938.3 \\
\hline T5 & 5 & 5.3 & 124 & 78.1 & 31.6 & 754.8 & 5.3 & 5.4 & 115.5 & 79 & 38 & 872.4 \\
\hline T6 & 4.7 & 5.3 & 128.7 & 78.6 & 34.7 & 793.9 & 5.6 & 5.5 & 120.4 & 80 & 38.5 & 880 \\
\hline $\mathrm{T} 7$ & 5.3 & 5.4 & 127.4 & 79.1 & 35.1 & 801.6 & 5.2 & 5.3 & 121.1 & 79.1 & 40 & 913.5 \\
\hline $\mathrm{T} 8$ & 5 & 5.5 & 116.1 & 79.1 & 35.2 & 780.9 & 5.6 & 5.3 & 121.1 & 78.4 & 38 & 867.8 \\
\hline T9 & 5.1 & 5.9 & 128.4 & 79.8 & 36.6 & 835.8 & 5.4 & $5.5)$ & 117.4 & 80.7 & 38 & 897.1 \\
\hline L.S.D $D_{0.05}$ & 0.74 & 1.33 & 20.3 & 6.94 & 7.41 & 152.4 & 0.98 & 0.95 & 16.04 & 5.5 & 4.5 & 102.9 \\
\hline
\end{tabular}


eggplant. They found that, spraying potassium silicate produced the highest values of yield and its components. The beneficial effects of silicon ( $\mathrm{Si}$ ) are mainly linked with high deposition in plant tissues, enhance strength and stiffness, this led to mechanical strength reduces housing, pest attacks and increase the light receiving position of the plant, increase photosynthesis and promote growth (Epstein, 1999), also supposed to reduce transpiration from the cuticle thus increasing resistance to salinity (Matoh et al., 1986)

\section{3- Chemical composition of dry seeds:}

According to chemical constituents in dry seeds, the data in Table (4) revealed that, Chemical composition of dry seeds i.e; N, P, K, crude protein, Zn and $\mathrm{B}$ in broad bean seeds were increased with all tested treatments. It is noticed that, foliar spraying with the Green miracle (T2) at the rate of $3 \mathrm{~cm} / \mathrm{L}$ gave high values of $\mathrm{N}, \mathrm{P}, \mathrm{K}$ and crude protein in dry seeds followed by foliar spraying with Naphthalene Acetic Acid (NAA) (T4) at the rate of $0.6 \mathrm{gm} \mathrm{/} \mathrm{L} \mathrm{and}$ potassium silicate (T5) at the rate of $3 \mathrm{~cm} / \mathrm{L}$. compared to other treatments or the control. Whereas, B content was high and increased by adding boron (B) (T4) at the rate of $1.5 \mathrm{gm} / \mathrm{L}$. Meanwhile, $\mathrm{Zn}$ content was markedly high and increased by spraying zinc (Zn) (T8) at the rate of $1.5 \mathrm{gm} / \mathrm{L}$. It might be concluded that, the highest values of $\mathrm{N}, \mathrm{P}, \mathrm{K}$, crude protein, $\mathrm{Zn}$ and $\mathrm{B}$ in dry seeds were attributed to the favorable effects of Green miracle which contains total amino acids which plays an important role in plant synthesis: Janska et al. (2009) demonstrated that plants received Green miracle have cryoprotective molecules such as soluble sugars (saccharose, raffinose, stachyose and trehalose), sugar alcohols (sorbitol, ribitol and inositol) and lowmolecular weight nitrogenous compounds (proline and glycine betaine). These results are came to the same conclusion with Sharief and El-hamady(2017) who concluded that spraying Naphthalene Acetic Acid up to $60 \mathrm{ppm}$ raised of total protein $\%$ of broad bean seeds. Abdel-Aziz and Geeth (2017) noticed that, foliar spraying with Green miracle as a stimulant substance at rate of $3 \mathrm{~cm}^{3} / \mathrm{L}$ significantly increased all chemical composition of pea cultivars. Geeth and Galal (2014) pointed out that, there were significantly increase in nitrogen and protein (\%) content in dry pea seeds by spraying amino acids at a rate of $100 \mathrm{ppm} / \mathrm{L}$. Khatab et al., (2016) illustrated that there were progressive increases in both $\mathrm{Zn}$ and $\mathrm{B}$ in broad bean seeds by increasing rates of the foliar applied of $\mathrm{Zn}$ and $\mathrm{B}$.

Table (4): chemical constituents of broad bean as affected by foliar spraying with growth improvers substances during the two winter seasons of 2017/2018 8and 2018/2019.

\begin{tabular}{|l|c|c|c|c|c|c|c|c|c|c|c|c|}
\hline \multirow{2}{*}{ Treatments } & \multicolumn{9}{|c|}{ 1st season } & \multicolumn{6}{c|}{ 2nd season } \\
\cline { 2 - 14 } & $\mathbf{N}$ & $\mathbf{P}$ & $\mathbf{K}$ & Protein & $\mathbf{Z n}$ & $\mathbf{B}$ & $\mathbf{N}$ & $\mathbf{P}$ & $\mathbf{K}$ & Protein & $\mathbf{Z n}$ & $\mathbf{B}$ \\
\hline T1 & 2.99 & 0.36 & 1.42 & 18.67 & 36.3 & 21.21 & 3.05 & 0.37 & 1.43 & 19.06 & 37.3 & 21.62 \\
\hline T2 & 3.87 & 0.85 & 1.93 & 24.18 & 51 & 33.93 & 3.88 & 0.86 & 1.94 & 24.25 & 51.3 & 33.85 \\
\hline T3 & 3.60 & 0.75 & 1.83 & 22.52 & 48 & 29.01 & 3.66 & 0.76 & 1.84 & 22.87 & 48 & 27.80 \\
\hline T4 & 3.64 & 0.81 & 1.84 & 22.77 & 49.3 & 28.54 & 3.67 & 0.83 & 1.84 & 22.93 & 49 & 28.56 \\
\hline T5 & 3.51 & 0.65 & 1.66 & 21.93 & 42.7 & 28.58 & 3.53 & 0.66 & 1.66 & 22.04 & 42 & 28.60 \\
\hline T6 & 3.59 & 0.72 & 1.75 & 22.42 & 47 & 26.18 & 3.54 & 0.71 & 1.76 & 23.90 & 47.6 & 27.59 \\
\hline T7 & 3.42 & 0.59 & 1.56 & 21.37 & 40.3 & 29.61 & 3.42 & 0.60 & 1.59 & 21.38 & 40.7 & 29.40 \\
\hline T8 & 3.37 & 0.48 & 1.49 & 21.06 & 59.7 & 28.76 & 3.39 & 0.49 & 1.48 & 21.17 & 60.3 & 28.76 \\
\hline T9 & 3.44 & 0.52 & 1.62 & 21.52 & 54.7 & 28.47 & 3.42 & 0.54 & 1.63 & 21.37 & 56 & 28.52 \\
\hline L.S.D 0.05 & 0.09 & 0.02 & 0.02 & 0.57 & 1.79 & 1.43 & 0.10 & 0.02 & 0.03 & 0.65 & 1.93 & 0.48 \\
\hline
\end{tabular}

$\mathbf{T}_{1}$ : control (spraying with tap water).

$\mathbf{T}_{2}$ : Foliar application of Green Miracle (G.M) (3cm / L).

$\mathbf{T}_{3}$ : Foliar application of Mono Potassium Phosphate (MKP) (6 gm / L).

$\mathbf{T}_{\mathbf{4}}$ : Foliar application of Naphthalene Acetic Acid (NAA) (0.6 gm / L).

$\mathbf{T}_{5}$ : Foliar application of potassium silicate $(3 \mathrm{~cm} / \mathrm{L})$.

$\mathbf{T}_{6}$ : Foliar application of fulvic acid $(1 \mathrm{~g} . / \mathrm{L})$.

$\mathbf{T}_{7}$ : Foliar application of Boron (B) $(1.5 \mathrm{~g} . / \mathrm{L})$.

$\mathbf{T}_{\mathbf{8}}$ : Foliar application of Zinc (Zn) (1.5 g. / L).

$\mathbf{T}_{\mathbf{9}}$ : Foliar application of (Zinc+ Boron) $(1.5+1.5$ g. / L). 
Abdel-Baky et al., (2019) showed that, applications of Fulvic acid (FA ) significantly improved the nutritional value and quality of faba bean seeds i.e.; crude protein, minerals (phosphorus, and potassium) content. Furthermore, Ismail and Shatta (2017) recorded that, foliar spraying of eggplant plants with potassium silicate significantly improved chemical constituents either in the leaves or in the fruits compared with control treatment during both seasons. On the other hand, Nesreen et al., (2012) found that, nitrogen, phosphorus and potassium concentrations and uptake not affected significantly by spraying bean plants with potassium silicate

\section{REFERENCES}

Abd El-Samad, H. M. and M. A. K. Shadadd (2013). The response strategy of maize, pea and broad bean plants to different osmotic potential stress. J Stress Physiol. \& Biochemistry 9 (3): 241-250.

Abdel-Aziz, M. A. and R. H. M. Geeth(2017): Effect of Spraying by Some Substances on Low Temperature Stress for Growth and Productivity in Late Peas (Pisum sativum L.) Planting under the Middle Egypt Region Conditions. J. Plant Production, Mansoura Univ., Vol. 8 (8): 859 - 867.

Abdel-Baky, Y. R., H. F. Abouziena, A. A. Amin, M. Rashad El-Sh and A. M. Abd El-Sttar (2019): Improve quality and productivity of some faba bean cultivars with foliar application of fulvic acid.

Ali, A. A. G. and S. A. E. Mowafy (2003). Effect of different levels of potassium and phosphorus fertilizers with the foliar application of zinc and boron on peanut in sandy soils. Zagazig J. Agric. Res. 30(2):335-358.

Anjum S.A., L. Wang, M. Farooq, L. Xue, S. Ali (2011). Fulvic acid application improves the maize performance under well watered and drought conditions. J. Agron. Crop Sci. 197:409-417.

Ankorion, J. (1998). MKP (monopotassium phosphate) for foliar fertilization in: proceedings of the symposium on foliar fertilization; A Technique to improve production and decrease pollution, cairo, Egypt, 10-14, December, pp; 71-84.

Black, C. A. (1965). Methods of soil analysis part IPhysical and Mineralogical Properties. A. S. A. Madison Wise., USA.

Bocanegra M.P., J.C. Lobartini and G.A. Orioli. (2006). Plant uptake of iron chelated by humic acids of different molecular weights. Commun Soil Sci Plant Anal 37:1-2.
Bulgari R., G. Cocetta, A. Trivellini, P. Vernieri and A. Ferrante.(2015). Biostimulants and crop responses: a review. Biol Agric Hortic 31(1):1-17.

Cho, M.H. No HK and W.Prinyawiwatkul(2008). Chitosan treatments affect growth and selected quality of sunflower sprouts. J. Food Sci, 73: 570- 577.

Crusciol, C. A. C.; A. L. Pulz; L. B. Lemos; R. P. Soratto and G. P. P. Lima (2009). Effects of silicon and drought stress on tuber yield and leaf biochemical characteristics in potato. Crop Physiology and Metabolism, 49: 949-954.

Dobbss L.B., L.O. Medici, L.E.P. Peres, L.E. PinoNunes, V. M. Rumjanek, A.R. Façanha,

Chen Y., C.E. Clapp, H. Magen (2004). Mechanisms of plant growth stimulation by humic substances: the role of organo-iron complexes. Soil Sci Plant Nutr 50: 10891095.

El-Gamal, S. I. (2009). physiological response of sugar beet (Beta vulgaris L.) plants to some nutrients and their relationship to cercospora leaf spot disease. M.SC. thesis, Dep. Agric. Botany, Fac. Agric., Banha, Univ.

El-Habbasha, S. F., M. H. Taha and N. A. Jafar (2013). Effect of nitrogen fertilizer levels and zinc foliar application on yield, yield attributes and some chemical traits of groundnut. Res. J. Agri. And Biol. Sci., 9 (1): 1-7.

Epstein, E. (1999). Silicon, Annual Review of Plant Physiology and Plant Molecular Biology, 50: 641-664.

Fageria, N. K., M. P. Barbosa Filho, A. Moreira and C. M. Guimaraes (2009). Foliar Fertilization of Crop Plants. J. of Plant Nutri., 32; 10441064.

Fawe, A. (1998). Silicon mediated accumulation of flavenoid phytoalexins in cucumber. Phytopathology, 88: 396-401.

Geeth, R. H. M. and R. M. Galal (2014). Response of pea plant (Pisum sativum L.) growth and yield for spraying of amino acids and boron. Egypt . J. of Appl. Sci., 29 (3):154-173.

Gerendas, J. and B. Sattelmatcher (1990). Influence of nitrogen form and concentration on growth and ionic balance of tomato (Lycoperiscum esculentum) and potato (Solanum tuberosum): In Plant Nutration Physiology and application (M.L. van Beusichem, ed).pp. 33-37.

Gupta, U. C. (1989). Effect of zinc fertilization on plant zinc concentration of forages and cereals. Can. J. Soil Sci., 69:473-479. 
Gupta, U.C. (1993). Boron and its role in crop production. Boca Raton, FL: CRC Press, USA, pp: 53-85.

Hanafy, E.M. Harb, M.A. Higazy, Sh.H. Morgan (2008). Effect of silicon and boron foliar applications on wheat plants grown under saline soil conditions. Inter. J. Agric. Res., 3(1): 1-26.

Hashemi, A., A. Abdolzadeh, H.R. Sadeghipour (2010). Beneficial effects of silicon nutrition in alleviating salinity stress in hydroponically grown canola (Brassica napus L.), plants. Soil Science and Plant Nutrition, 56(2): 244253.

Hubbell, D. H. and K. Gerald (2003): Biological nitrogen fixation. Fact sheet of the Soil and Water Science Department, Florida Cooperative Extension Service, Institute of food and agricultural sciences, University of Florida, pp:4.

Hussein, W.A. and M.M. Muhammed (2017). The response of white eggplant plants to foliar application with boron and potassium silicate. Assiut J. Agric. Sci., 48 (1): 394-401.

Ibrahim, I. S. A.B. Abdel-Razik and Naglaa M. Ebeed (2007). Effect of some plant growth regulators on biochemical gene Expression, growth and yield of faba bean. Pak. J. Biotechnology, 4 (1-2) 47- 64.

Ismail, E. E. M. and M. A. M. Shatta(2017). Effect of some Treatments on Reducing Salinity Injuries Effect on Growth, Yield and Quality of Eggplant. J. Plant Production, Mansoura Univ., and Vol. 8 (12): 1421 - 1429.

John, M.K. (1970). Colorimeteric determination of phosphoruse in soil plant materials with ascorbic acid. Soil Sci., 109: 214-220.

Khatab, A. KH. M. F. ABD EL-Aziz and Nadia, M.Hemeid(2016). Implication of foliar spray of $\mathrm{Zn}$ and/or $\mathrm{B}$ on growth of broad bean (Vicia faba L) and its uptake of some nutritive elements. Proceedings of 1st International Conf. of Applied MicrobiologyMarch 1-3,151-162.

Khayyat, M., E. Tafazoli, S. Eshghi and S. Rajaee (2007). Effect of nitrogen, boron, potassium and zinc sprays on yield and fruit quality of date palm. Am Eurasian J Agric Environ. Sci., 2: 289-296.

Lee H.S. (1990): Effect of pre-sowing seed treatment with GA3 and IAA on flowering and yield components of groundnut. Korean. J. Crop Sci., 35(1): 1- 9 .
Lindsay, W.L. and W. A. Norvell (1978). Development of a DTPA micronutrient soil tests for zinc, iron, manganese, and copper. Soil Sci. Soc. Amer. J. 42:421-428.

Mahady, A. E. M. (1990). Effect of phosphorus fertilizer, some micronutrients and plant density on growth and yield of broad beans. Ph.D. Thesis, Faculty of Agric., Zagazig University, Benha Branch.

Marschner, H. (1995). Mineral Nutrition of Higher Plants. $2^{\text {nd }}$ ed., Acadimic press. Pub. New York (USA).

Marschner, H. (2005). Mineral Nutrition of Higher Plants. Academic Press, London, UK, pp.889.

Matoh, T., P. Kairusmee and E. Takahashi( 1986). Salt induced damage to rice plants. Australian J. Basic and Applied Sci., 5 (9): 769-781.

Michniewiczand, B. M. R.(1988): Is the gibberellinlimiting factor for the growth and development of Fusariumculmorum? Acta Physiol. Plant, 10, 227- 236.

Mortvedt, J. J.; F. R. Cox; L. M. Shuman and R. M. Welch (1991). Micronutrients in agriculture, 2nd ed. Published by Soil Soc. Amer. Inc. Madison, Wisconsin, USA, 760 pp.

Murphy, J. and J.P. Riely. (1962). A modified single solution method for determination of phosphate in natural. Anal. Chim. Acta., 29:31-36.

Nesreen H. Abou-Baker, Abd-Eladl M. and T.A. Eid (2012). Silicon and Water Regime Responses in Bean Production under Soil Saline Condition. J. of Applied Sciences Research, 8(12): 5698-5707.

Page A. L., R. H. Miller and D. R. Keeney (1982): Methods of Soil Analysis. Part (II) Chemical and Microbiological Properties. A. S. A. Madison Wisc., USA.

Pendias, A. K. and H. Pendias (2001). Trace elements in soils and plants. CRC Press, Washington DC.

Pilbeam, D.J. and E.A. Kirkby (1983). The physiological role of boron in plants. J. Plant Nutr., 6: 563-582.

Pregl, F. (1945). Quantitative Organic Micro Analysis. 4 ${ }^{\text {th }}$, Ed. J. Churchill Ltd. London.

Rakha, M.K.A. (2014). Growth, yield and fruit quality of eggplant (Solanum melongena L.) as affected by irrigation intervals and foliar application of some antitranspirants. J. Plant Production, Mansoura Univ., 5 (12): 20692083. 
Salami M. and S. Saadat( 2013). Study of potassium and nitrogen fertilizer levels on the yield of sugar beet in jolge cultivar. J. of Novel Applied Sci., 2(4):94-100.

Sepetoglu, H. (2002). Grain legumes. Ege Univ. Fac. of Agric. Publication, 24/4, 262.

Sharief, A. E. and M. M. El-hamady(2017). Influence of Growth Regulators on Shedding of Broad Bean, Growth, Yield and Seed Quality. International J. of Environment, Agric. and Biotechnology (IJEAB) Vol-2: 954-959.

Snedecor, G. A. and W. G. Cochran (1980). Statistical Methods, $7^{\text {th }}$ Ed., the Iowa State Univ., Press, Ames., Iowa, U.S.A.

Tahir, M.A., T. Rahmatullah, Aziz, M. Ashraf, S. Kanwal, M.A. Maqsood( 2006). Beneficial Effects of Silicon in Wheat (Triticum Aestivum L.) Under Salinity Stress. Pakistan J. Botany, 38(5): 1715-1722.

Tersahima, I. and J.R. Evans (1988). Effect of light and nitrogen nutrition on the organization of the photosynthetic apparatus in spinach. Plant Cell Physiol., 29: 143-155.
Thalooth, A. T., N. M. Baadr and M. H. Mohamed (2005).Effect of foliar spraying with zinc and different levels of phosphatic fertilizer on growth and yield of sun flower plants grown under saline conditions. Egypt. J. Agro. 22:11-22.

Trehan, S. P. and G. S. Sekhon (1977). Effect of clay, organic matter, and $\mathrm{CaCO} 3$ content on zinc adsorption by soils. Plant Soil 46: 329336.

Wang, M.; Q. Zheng, Q. Shen and S. Guo (2013). The critical role of potassium in plant stress response. International journal of molecular sciences, 14(4):7370-7390.

WHO (2002). World Health Report Reducing risks, promoting healthy life. World Health, Organization, Geneva, Switzerland.

Wojcik, P., G. Cieslinski and A. Mika (1999). Apple yield and fruit quality as influenced by boron applications. J. Plant Nutr. 22(9): 1365-1377.

Zimmerli L, B.H. Hou, C.H. Tsai, G. Jakab, B. Mauch-Mani and S. Somerville .(2008). The xenobiotic beta-aminobutyric acid enhances Arabidopsis thermotolerance. Plant J. 53:144-156. 


\section{استجابة محصول البذور للفول الرومي للرش بالاحماض الامينية والاحماض العضوية}

\section{ومنظم النمو نفالين استيك أسيد والعناصر الصغري}

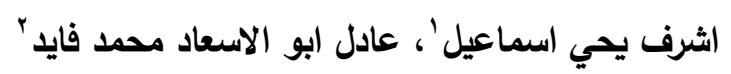

قسم بجوث تكنولوجيا انتاج تقاوي الخضر - معهل بحوث البساتين - مركز البحوث الززاعيه

الجيزه - مصر

اجريت تجارب حقليه بمحطه بحوث البساتين بسخا - مركز البحوث الزراعيه -جمهوريه مصر العربيه, خلال

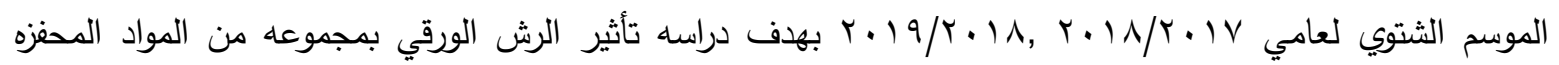

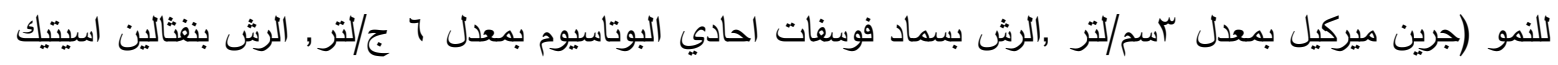

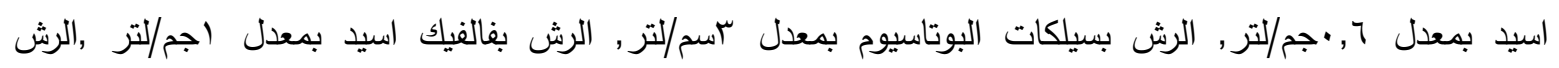

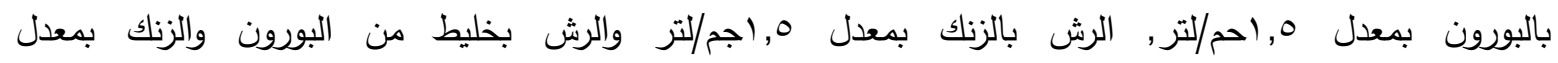

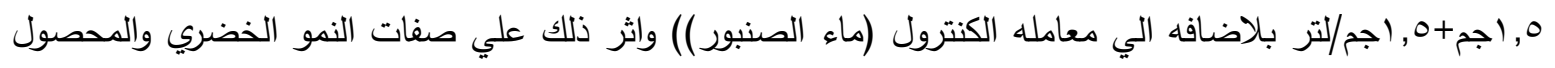

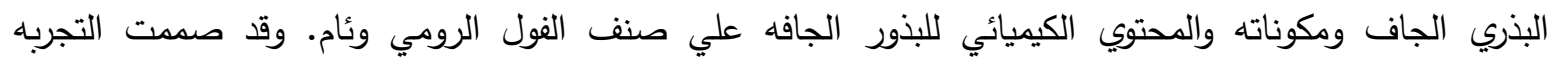

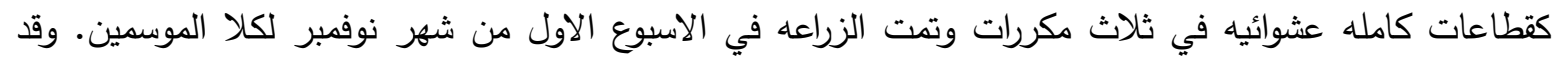

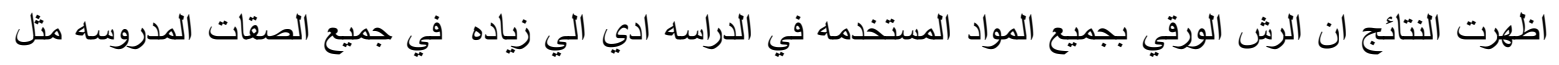

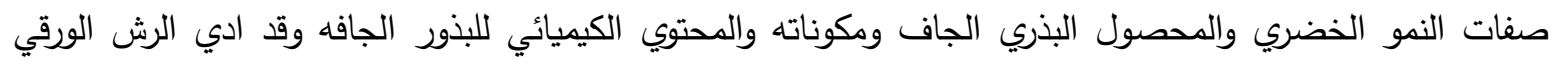

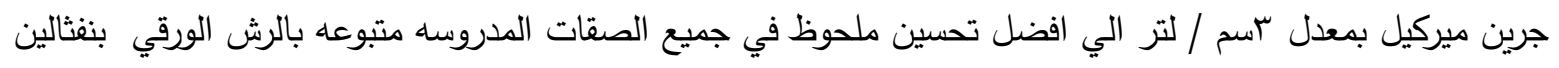

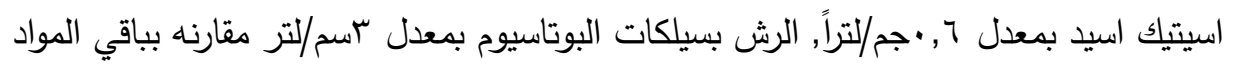

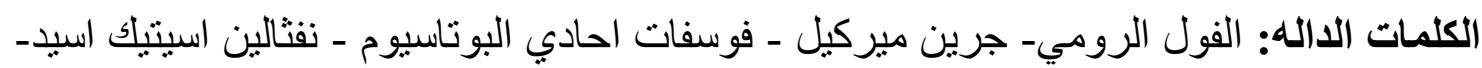
سيكات البوتاسيوم - حمض فالفيك - البورونـ الزين مئك. 